Jurna I Instruksional, Volume 1, Nomor 2, April $2020 \mid 159$

ISSN: 2686-5645

\title{
GOOGLE TRANSLATE SEBAGAI ALTERNATIF MEDIA PENERJEMAHAN TEKS BAHASA ASING KE DALAM BAHASA INDONESIA
}

\author{
Adi Alam \\ Pendidikan Teknologi Informasi, Universitas Muhammadiyah Jakarta \\ email: adi.alam@umj.ac.id
}

\begin{abstract}
The development of Information and Communication Technology (ICT) is progressing very rapidly. Due to the strong era of globalization where computers and the dynamic internet become facilities that have dominated various life activities, so educational activities also require the availability of these facilities. Google Translate becomes one of the translation machines that can be used by academics in translating literature written in foreign languages. Google Translate is one of the media that can make it easier for someone to translate text from various languages into the desired language. This paper uses a descriptive qualitative approach with this literature study method aimed at describing the process of translating foreign language texts and pronunciation into appropriate Indonesian. The media can be used to translate text, both by word, phrase, clause, sentence, and even discourse. However, it is often found errors and irregularities in the translation of the entered text. The results of this study are that academics are greatly helped by the existence of the Google Translate application as a learning medium. Despite the lack of this application, learning academics still have a positive perception of their use. They believe that the results of the translation will remain accurate as long as they can match the context.
\end{abstract}

Keywords: Google Translate, translation, learning media

\begin{abstract}
Abstrak
Perkembangan Teknologi Informasi dan Komunikasi (TIK) mengalami kemajuan yang sangat pesat. Dikarenakan oleh kuatnya era globalisasi dimana komputer dan internet yang sifatnya dinamis menjadi fasilitas yang telah mendominasi berbagai kegiatan kehidupan, sehingga aktivitas pendidikan pun memerlukan ketersediaan fasilitas tersebut. Google Translate menjadi salah satu mesin penerjemahan yang bisa digunakan oleh para akademisi dalam menerjemahkan literatur-literatur yang ditulis dalam bahasa asing. Google Translate merupakan salah satu media yang dapat memudahkan seseorang untuk menerjemahkan teks dari suatu bahasa ke bahasa lainnya. Tulisan ini menggunakan pendekatan kualitatif deskriptif dengan metode studi pustaka ini bertujuan mendeskripsikan proses penerjemahan teks dan pengucapan bahasa asing menjadi bahasa Indonesia yang sesuai. Media tersebut dapat dimanfaatkan untuk menerjemahkan teks, baik secara per kata, frasa, klausa, kalimat, dan bahkan wacana. Namun demikian, seringkali menemukan kesalahan dan kejanggalan dalam penerjemahan teks yang dimasukkan. Hasil dari penelitian ini adalah bahwa akademisi sangat terbantu dengan adanya aplikasi Google Translate sebagai media pembelajaran. Walaupun ada kekurangan dari aplikasi ini, akademisi belajar tetap memiliki persepsi positif terhadap penggunaannya. Mereka meyakini bahwa hasil terjemahan akan tetap akurat selama masih bisa mencocokkan dengan konteks.
\end{abstract}

Kata kunci: Google Translate, penerjemahan, media pembelajaran

\section{PENDAHULUAN}

Pendidikan merupakan hal yang penting dalam kehidupan manusia. Seiring berjalannya waktu, pendidikan pun mengalami perubahan. Di dalam proses perubahan dalam pendidikan ini peran guru menjadi sangat vital. Pemeran utama dalam proses belajar mengajar di sekolah adalah guru, peran guru di sekolah memiliki peran ganda. Di pundak mereka itulah terdapat mutu pendidikan. Guru bisa juga disebut sebagai seorang manajer yang mengelola proses pembelajaran, perencanaan, mendesain pembelajaran, melaksanakan akivitas pembelajaran bersama-sama dengan para siswa, serta melakukan proses kontrol atas kecakapan dan prestasi siswa.

Pendidikan itu bisa juga dikatakan sebagai proses interaksi antar manusia. Interaksi antara pendidik dan peserta didik, 
antara orang tua dan anak, antara guru dan murid serta lingkungan dan para pembelajar. Dimana posisi guru adalah sebagai inti daripada proses pendidikan itu sendiri.

Hal yang relevan dengan dunia pendidikan bahasa dan sastra tercermin melalui pertanyaan: Bagaimana Google Translate membantu proses penerjemahan teks dan pengucapan bahasa asing menjadi bahasa Indonesia yang sesuai? Penerjemahan sebagai salah satu aplikasi dari linguistik terapan mampu menjadi jembatan dalam mengalihkan pesan dari bahasa yang satu ke dalam bahasa yang lain. Dalam mengalihkan pesan sebuah teks dari bahasa sumber ke dalam bahasa sasaran, penerjemah harus memperhatikan aspek semantik dan juga ekuivalensi dalam TSa dan TSu. Artinya bahwa tidak hanya pesan saja yang perlu diperhatikan pada saat menerjemahkan tetapi penerjemah perlu memperhatikan aspek semantik dan juga ekuivalensi.

Pada zaman sekarang ini, penerjemahan memiliki peranan yang sangat penting, khususnya di dalam dunia akademik yang banyak menggunakan literatur-literatur berbahasa asing, misalnya bahasa Inggris yang sering menjadi kendala bagi para akdemisi yang memiliki pemahaman bahasa Inggris yang kurang bagus. Oleh karena itu, salah satu aplikasi dari penerjemahan dengan memanfaatkan teknologi adalah dengan pemakaian Google Translate atau mesin penerjemahan dengan aplikasi Google yang bisa digunakan untuk mengalihkan pesan dari bahasa asing ke dalam bahasa Indonesia. Google Translate dapat menerjemahkan mulai dari kata, frasa, klausa, kalimat, dan bahkan wacana. Mesin penerjemahan ini sangat membantu untuk menerjemahkan bahasa asing ke dalam bahasa Indonesia.

Namun demikian, kendala yang umumnya dihadapi oleh para akademisi pada saat menggunakan mesin tersebut adalah bahwa mereka hanya copy paste seluruh teks yang diterjemahkan ke dalam mesin Google Translate sehingga hasil yang diharapkan dari terjemahan tersebut seringkali membingungkan dan tidak sepadan ke dalam bahasa sasaran.

Penelitian ini secara khusus akan mengkaji tentang pemanfaatan mesin Google Translate sebagai alat bantu dalam penerjemahan teks dan pengucapan bahasa asing.

\section{KAJIAN LITERATUR Penerjemahan}

Penerjemahan adalah "rendering the meaning of a text into another language in the way that the author intended the text" (Newmark, 1988). Menerjemahkan makna suatu teks ke dalam bahasa lain sesuai dengan yang dimaksudkan pengarang). Sedangkan menurut Bell yang mendefinisikan penerjemahan sebagai "Translation is the expression in another language (or target language) of what has been expressed in another, source language, preserving semantic, and stylistic equivalences" (Bell, 1991). Penerjemahan sebagai suatu bentuk pengungkapan suatu bahasa dalam bahasa lainnya sebagai bahasa sasaran, dengan memperhatikan semantik dan ekuivalensi.

Konsep penerjemahan yang diungkapkan oleh Newmark lebih menekankan bahwa penerjemahan bukan hanya mengalihkan pesan dari bahasa sumber ke dalam bahasa sasaran tetapi harus memahami bahasa sasaran dan maksud yang ingin disampaikan oleh pengarang agar tidak terjadi kesalahan. Hal senada diungkapkan oleh Roger T. Bell yang mendefinisikan penerjemahan sebagai "Translation is the expression in another language (or target language) of what has been expressed in another, source language, preserving semantic, and stylistic equivalences." Penerjemahan sebagai suatu bentuk pengungkapan suatu bahasa dalam bahasa lainnya sebagai bahasa sasaran, dengan memperhatikan semantik dan ekuivalensi, (1991: 5).

Catford menggunakan pendekatan kebahasaan dalam melihat kegiatan penerjemahan dan ia mendefinisikannya sebagai "the replacement of textual material in one language (SL) by equivalent textual 
material in another language (TL)" yaitu (mengganti bahan teks dalam bahasa sumber dengan bahan teks yang sepadan dalam bahasa sasaran), (Catford, 1965:20).

Mengacu pada pendapat Catford, dapat disimpulkan bahwa inti dari penerjemahan adalah mengalihkan bahasa sumber ke bahasa sasaran sama baik dengan bahasa aslinya. Senada dengan Catford, Nida dan Taber mendefinisikan penerjemahan sebagai "translating consists in reproducing in the receptor language the closest natural equivalent of the source language message, first in terms of meaning and secondly in term of style", penerjemahan merupakan pengungkapan kembali di dalam bahasa penerima $(\mathrm{BSa})$ padanan yang terdekat dan wajar dari pesan dalam bahasa sumber, pertama dalam hal makna dan kedua dalam hal gaya (Nida dan Taber, 1983: 12).

Pada saat mengalihkan pesan ke dalam teks sasaran, penerjemah perlu mencari padanan makna yang terdekat dan wajar sesuai dengan makna dalam bahasa sumber. Penerjemahan melibatkan pengalihan pesan dari bahasa sumber ke dalam bahasa sasaran. Bisa dikatakan bahwa terdapat dua bahasa yang berbeda yang akan disampaikan dengan pesan yang serupa. Konsep ini dalam penerjemahan biasa disebut dengan kesepadanan penerjemahan.

Konsep kesepadanan diungkapkan oleh Eugene A. Nida. Ia membagi kesepadanan menjadi dua, yakni kesepadanan formal dan kesepadanan dinamis. Kesepadanan formal berorientasi pada teks sumber. Penerjemahan didesain untuk menghadirkan teks bahasa sasaran yang sama seperti bentuk dan isi pesan pada teks bahasa sumber. Dalam menempuh kesepadanan formal, ada beberapa elemen formal yang harus diperhatikan, yaitu (1) unit gramatikal, misalnya penerjemahan nomina harus menjadi nomina, verba menjadi verba, semua frasa dan kalimat harus utuh, mempertahankan indikator formal; (2) konsistensi pada pengguna kata, dan (3) makna pada konteks sumber tidak boleh membuat idiom ataupun menghasilkan ekspresi yang literal (Nida, 1964: 165-167). Kesepadanan dinamis fokus langsung kepada pesan dalam bahasa sumber untuk disampaikan kapada pembaca. Kesepadanan dinamis mengandung tiga hal utama, yakni (1) ekuivalensi, berkaitan dengan pesan pada bahasa sumber kepada pembaca, (2) kewajaran yang mengacu kepada bahasa sasaran, meliputi penerima bahasa dan juga budaya secara keseluruhan, konteks, dan audiens (3) kedekatan yang berorientasi pada tingkat kedekatan.

\section{Media Pembelajaran}

Istilah media berasal dari bahasa Latin yang merupakan bentuk jamak dari "medium" yang secara harfiah berarti perantara atau pengantar. Makna umumnya adalah segala sesuatu yang dapat menyalurkan informasi dari sumber informasi kepada penerima informasi (Depdiknas, 2003). Proses belajar mengajar pada dasarnya juga merupakan proses komunikasi, sehingga media yang digunakan dalam pembelajaran disebut media pembelajaran. Media pembelajaran merupakan bagian dari sumber belajar yang merupakan kombinasi antara bahan belajar dan alat belajar

\section{METODE PENELITIAN}

Penelitian ini menggunakan pendekatan kualitatif deskriptif dengan metode studi pustaka (library research). Penelitian deskriptif kualitatif adalah penelitian mendeskripsikan data apa adanya, menjelaskan data atau kejadian dengan kalimat-kalimat penjelasan dengan cara kualitatif (Moleong, 2012: 6). Sementara studi kepustakaan di sini merupakan pengumpulan data dengan mengadakan studi penelaahan buku-buku, literaturliteratur, catatan-catatan, dan laporanlaporan yang berhubungan dengan masalah yang dipecahkan (Nazir, 2003: 27).

Tulisan ini menerapkan pendekatan analisis deskriptif yang berkaitan dengan kajian-kajian literatur tentang proses penerjemahan bahasa asing dengan menggunakan Google Translate. Analisis deskriptif dalam hal ini menggunakan statistik untuk menganalisis data dengan 
cara mendeskripsikan atau menggambarkan data (Sugiyono, 2005: 169).

\section{HASIL DAN PEMBAHASAN}

Di bidang pembelajaran bahasa, teknologi digital membuat beberapa aspek pembelajaran menjadi jauh lebih cepat dan efisien. Teknologi digital sekarang menyediakan guru mesin yang bersenjatakan algoritma dari kecerdasan buatan untuk mengajarkan pengucapan, makna kata, tata bahasa, bahkan menulis. Peningkatan penguasaan dan pengucapan kosakata yang dikuasai akan terbantu dengan adanya aplikasi Google Translate. Peningkatan ini diindikasikan dengan semakin baiknya kemampuan pengguna dalam memahami teks bahasa asing dan pengucapan kosakata yang benar. Penggunaan Google Translate membantu mempercepat penguasaan kosakata karena, dapat digunakan secara langsung dan praktis, tanpa perlu menggunakan kamus bahasa Inggris. Menunjukan bahwa penggunaan Google Translate sebagai media pembelajaran dapat meningkatkan penguasaan dan pengucapan kosakata seseorang.

Walaupun ada juga beberapa masalah yang terkadang dihadapi oleh pengguna Google Translate, di antaranya yaitu : (1) Google Translate sering menggunakan penerjemahan kata per kata sehingga para pengguna sering terkecoh dengan penerjemahan tersebut; (2) Perbedaan struktur bahasa sumber dan bahasa Indonesia; (3) Tidak mencari padanan dalam bahasa sasaran, sehingga makna yang dihasilkan menjadi rancu dan tidak jelas. Karena itu ada beberapa langkah yang bisa kita lakukan untuk mengatasi permasalahan di atas, yaitu dengan (1) Dengan memasukkan seluruh teks ke dalam mesin Google Translate. Teks dapat diterjemahkan secara per kata, frasa, klausa, kalimat, dan juga wacana; (2) Salin teks terjemahan ke dalam Microsoft Word; (3) Setelah selesai menyalin ke dalam Microsoft Word, maka langkah berikutnya adalah membaca teks secara keseluruhan dan memahami maksud yang ingin disampaikan dalam bahasa sasaran; (4) Menyusun teks sasaran sesuai dengan struktur dalam bahasa sasaran. Langkah terakhir yang bisa dilakukan adalah dengan mencari padanan yang tepat dan menyesuaikan dengan struktur bahasa Indonesia.

Google Translate digunakan sebagai alat bantu untuk memberi arti kata dalam materi yang diajarkan kepada peserta didik. Kegunaan lain dari Google Translate selain untuk menerjemah yaitu untuk belajar pengucapan dan menambah kosa kata. Pengguna akan terbantu sekali dengan adanya aplikasi ini untuk memahami materi pelajaran yang berbahasa asing yang mana untuk memahaminya mereka harus menerjemah terlebih dahulu. Google Translate yang berupa aplikasi tentu saja jauh lebih simpel dibandingkan harus membawa kamus. Dalam pengaplikasian di bidang ilmu, khususnya dalam bidang penerjemahan, berupaya memberikan solusi penerjemahan dengan Google Translate sehingga terjemahan yang dihasilkan sepadan dan sesuai dengan bahasa sasaran.

\section{KESIMPULAN}

Berdasarkan pemaparan di atas, dapat disimpulkan bahwa penggunaan Google Translate ini bisa menjadi salah satu solusi bagi akademisi untuk memahami teks secara keseluruhan sehingga bisa menjadi solusi dalam memahami teks bahasa asing atau literatur-literatur dalam bahasa asing. Namun, para akademisi harus dapat memahami kedua struktur bahasa dan budaya dalam bahasa sumber dan bahasa sasaran sama baiknya sehingga kesalahan dalam memahami teks dapat diminimalisir dan bisa menjadi solusi dalam memahami teks bahasa asing.

\section{REFERENSI}

Bayu, Krisna. 2020. Penggunaan Google Translate sebagai Media Pembelajaran Bahasa Inggris Paket B di PKBM Suryani. Jurnal COMM-EDU, Volume 3 Nomor 1, Januari 2020. 
Bell, Roger T. 1991. Translation and Translating: Theory and Practice. New York: Routledge.

Catford. J.C. 1965. A Linguistic Theory of Translation: An Essay in Applied Linguistics. London: Oxford University Press.

Machali, Rochayah. 2000. Pedoman Bagi Penerjemah. Jakarta: PT Grasindo.

Moleong, Lexy J. 2012. Metodologi Penelitian Kualitatif, Bandung: PT. Remaja Rosdakarya.

Nazir. Moh. 2003. Metode Penelitian. Jakarta: Ghalia Indonesia.

Newmark, Peter. 1988. A Textbook of Translation. London: Prentice Hall International.

Nida, Eugene A dan Taber, Charles R. 1983. The Theory and Practice Translation. Leiden: E. J Brill.

Pujiati, Tri. 2017. Pemanfaatan Google Translate dalam Penerjemahan Teks Bahasa Inggris ke dalam Bahasa Indonesia (Aplikasi Linguistik Terapan Bidang Penerjemahan) dalam Prosiding Seminar Ilmiah Nasional: Jakarta.

Sugiono. 2005. Metode Penelitian Bisnis. Bandung: Alfabeta. 